\title{
A Highly Sensitive SERS and RRS Coupled Di-Mode Method for CO Detection Using Nanogolds as Catalysts and Bifunctional Probes
}

\author{
Dongmei Yao ${ }^{1,2,3}$, Guiqing Wen ${ }^{1,2}{ }^{10}$, Lingbo Gong ${ }^{1,2}$, Chongning $\mathrm{Li}^{1,2}$, Aihui Liang ${ }^{1,2, *}$ and \\ Zhiliang Jiang $1,2, * \mathbb{D}$ \\ 1 Key Laboratory of Ecology of Rare and Endangered Species and Environmental Protection (Guangxi Normal \\ University), Ministry of Education, Guilin 541004, China; dmyao47@163.com (D.Y.); \\ gqwen@mailbox.gxnu.edu.cn (G.W.); zljiang89@126.com (L.G.); lcn7882342@163.com (C.L.) \\ 2 Guangxi Key Laboratory of Environmental Pollution Control Theory and Technology for Science and \\ Education Combined with Science and Technology Innovation Base, Guilin 541004, China \\ 3 College of Chemistry and Biology Engineering, Hechi University, Yizhou 546300, China \\ * Correspondence: ahliang2008@163.com (A.L.); zljiang@mailbox.gxnu.edu.cn (Z.J.)
}

Received: 31 January 2020; Accepted: 28 February 2020; Published: 2 March 2020

\begin{abstract}
Carbon monoxide (CO) is a commonly poisonous gas. It is important to detect $\mathrm{CO}$ in daily life. Herein, a new and sensitive surface enhanced Raman scattering (SERS) and resonance Rayleigh scattering (RRS) coupled di-mode method was developed for CO, based on gold nano-enzyme catalysis and gold nanoprobes. $\mathrm{CO}$ can react with $\mathrm{HAuCl}_{4}$ to generate gold nanoparticles (AuNPs) in pH 5.2 HAc-NaAc buffer. The generated AuNPs exhibited SERS activity at $1620 \mathrm{~cm}^{-1}$ in the presence of Vitoria blue B (VBB) molecular probes, and an RRS peak at $290 \mathrm{~nm}$. Based on the AuNP bifunctional probes, the increased SERS and RRS intensities respond linearly with the concentration of CO in the range of $100-1500 \mathrm{ng} / \mathrm{mL}$ and $30-5230 \mathrm{ng} / \mathrm{mL}$, respectively. To improve the sensitivity, the produced AuNPs were used as nano-enzyme catalysts for the new indicator reaction of $\mathrm{HAuCl}_{4}$-ethanol (En) to amplify the signal. The sensitive SERS method was coupled with the accurate RRS method to develop a sensitive and accurate SERS/RRS di-mode method for determination of 3.0-413 ng/mL CO, based on the AuNP-HAuCl 4 -En nanocatalytic reaction and its product of AuNPs as SERS and RRS bifunctional probes.
\end{abstract}

Keywords: CO; nanocatalysis; SERS; RRS; coupled di-mode

\section{Introduction}

The progress and continuity of metabolic and genetic information transmission in life-sustaining activities are closely related to the orderly chemical reactions in vivo, and enzymes are the key to catalyzing these chemical reactions to proceed smoothly. Bio-enzymes have the advantages of high catalytic efficiency, selectivity of substrates and wide range of catalytic reactions, but their application in production practice is greatly limited because of their high production cost, high cost of preservation and transportation, harsh use conditions and narrow scope [1-4]. Since the discovery of $\mathrm{Fe}_{3} \mathrm{O}_{4}$ nanomaterials with catalytic properties similar to horseradish peroxidase [5], nano-enzymes have attracted much attention. Nano-enzymes have the characteristics of high catalytic efficiency, stability, economy and large-scale preparation. They have been applied in medicine, chemical industry, food, agriculture, environment and analytical chemistry. The catalytic activity of nano-enzymes is higher than that of many traditional mimetic enzymes. Traditional mimetic enzymes are mostly based on organic complexes, using the molecular structure and microenvironment of mimetic enzymes' catalytic centers such as polymer micelles or molecular imprinting technology. The common 
problem of these mimetic enzymes is that their catalytic activity and selectivity are low, and their preparation cost is high. So far, these mimetic enzymes can not meet the actual needs. However, nano-enzymes have similar catalytic activities to natural enzymes. The most important feature of nano-enzymes is that they have unique physical and chemical properties of nanomaterials besides catalytic functions. Therefore, nano-enzymes are also considered as bifunctional or multifunctional molecules. How to skillfully combine the catalytic activity of nano-enzymes with their physical and chemical properties to create more unique new functions will be a new subject to be studied. In analytical chemistry, nano-enzymatic reactions have been used in spectrophotometry, fluorescence and chemiluminescence [6-8]. Jiang et al. found that gold nanoparticles have catalase-like activity and can catalyze the oxidation of 3,3,5,5-tetramethylbenzidine (TMB) by $\mathrm{H}_{2} \mathrm{O}_{2}$ to produce a blue product [9]. Coupled glucose peroxidase (GOx) and gold nanoparticles can be used for the spectrophotometric determination of glucose content, with a linear range of $18-1100 \mu \mathrm{mol} / \mathrm{L}$, and a detection limit of $4 \mu \mathrm{mol} / \mathrm{L}$. Liu et al. prepared platinum nanodots in situ on gold nanorods. The nanocomposite could catalytically oxidize o-phenylenediamine (OPD) to produe yellow product, and the coupling GOx could detect glucose spectrophotometrically [10]. Based on the catalysis of immune nanoprobes and aptamer nanoprobes, they are also used in resonance Rayleigh scattering (RRS) and surface enhanced Raman scattering (SERS) quantitative analyses, respectively [11,12].

SERS is a sensitive molecular spectral detection technique based on nanosurface plasmon resonance including solid nanosurface and nanosol [13-16]. SERS works have not only been focused on the qualitative analysis but also on the quantitative analysis, especially, the improvement of its accuracy. To improve precision, some procedures were reported, such as the internal standard method and SERS/fluorescence di-mode method [12,17]. RRS uses molecular scattering, which can occur when the particle size is much smaller than the wavelength of incident light. The diameter of gold or silver nanoparticles is usually less than $50 \mathrm{~nm}$, which is much smaller than the wavelength of the incident light. Therefore, gold or silver nanoparticles are often used as carriers for the RRS phenomenon. RRS is a simple, rapid and sensitive spectral analysis technology, which was used in nucleic acids, proteins, and small molecule analyses [18-24]. However, there are rare reports about the detection of gas pollutants by RRS. Wen et al. [25] established a rapid RRS method for $0.2-50 \mu \mathrm{mol} / \mathrm{L} \mathrm{O}_{3}$, based on the generation of tri-iodine ion $\left(\mathrm{I}_{3}{ }^{-}\right)$reacting with Victoria blue $\mathrm{B}(\mathrm{VBB})$ to form the associated particle $(\text { VBB-I })_{3}$ with an RRS peak at $722 \mathrm{~nm}$. To the best of our knowledge, there are no reports about coupling SERS with RRS to set up a SERS/RRS di-mode method for quantitative analysis of $C O$, based on the produced AuNP catalysis of the $\mathrm{HAuCl}_{4}$-En-VBB system.

$\mathrm{CO}$ is a kind of colorless, odorless, poisonous gas, which is mainly generated by automobiles, incomplete combustion of fossil fuels, industrial production and residential environments [26,27]. People with chronic poisoning of carbon monoxide pollution cannot be aware of it completely, sometimes even feeling comfortable, which makes carbon monoxide more harmful. The chemical affinity of $\mathrm{CO}$ with hemoglobin is 300 times stronger than that of $\mathrm{O}_{2}$, and considering its toxicity and difficulty to be detected, $\mathrm{CO}$ is regarded a very dangerous "silent killer" [28]. Many researchers have studied how to quickly and accurately detect $\mathrm{CO}$, most studies focus on new sensors. Kim et al. [29] developed a $\mathrm{Pd} / \mathrm{SnO}_{2}$ sensors that can detect $\mathrm{CO}$ below $60^{\circ} \mathrm{C}$. Boehm et al. [30] produced a device based on InP and GaSb. This device has two ways of the continuous wave mode to detect $\mathrm{CO}$, which makes it possible for the lower limit of detection to reach $2.0 \mu \mathrm{g} / \mathrm{mL}$. Wang et al. [31] studied the reactions of $\mathrm{CO}$ and $\mathrm{NO}$ in single wall boron nitride nanotubes (BNNTs) mixed with Ge. They showed that the performance of BNNTs was improved for CO and NO detection. Ghosh et al. [32] introduced a kind of stable and economically viable sensor based on $\mathrm{SnO}_{2}$ nanocrystals. It can achieve determination of $\mathrm{CO}$ in the air, with a detection limit of $1.0 \mu \mathrm{g} / \mathrm{mL}$. Chen et al. [33] used bovine hemoglobin with a high affinity for $\mathrm{CO}$ to combine dissolved $\mathrm{CO}$ in water to form a two-component system consisting of hemoglobin $(\mathrm{Hb})$ and carboxyhemoglobin $(\mathrm{HbCO})$. CO content can be detected quantitatively using a tilapia color pool through fast and simple double wavelength ultraviolet visible spectrophotometry, of which the detection range achieved $0-0.15 \mu \mathrm{g} / \mathrm{mL}$ and the detection limit 
was $0.23 \mu \mathrm{g} / \mathrm{L}$. Chen et al. [34] reported a sensor using a quantum cascade laser with an excitation wavelength of $4.65 \mu \mathrm{m}$ as the light source, with a detection limit of $108 \mathrm{ppb}$. Zoltan et al. [35] studied a method which can detect $\mathrm{CO}$ concentration and total pressure of the light bulb plenum chamber in order to control the chemical purity of molybdenum foil indirectly through traditional Fourier transform infrared spectroscopy. Wang et al. [36] established a quick and easy method of CO detection for aquatic products, in which the detection limit reached $10 \mu \mathrm{g} / \mathrm{kg}$. Wang et al. [37] prepared a near-infrared fluorescent probe for the determination of $\mathrm{CO}$, based on the transformation of a nitro group into an amino moiety under the direct reduction of CO. Hao et al. [38] established a kind of headspace gas chromatography-mass spectrometry (HS/GC/MS) method for the precise determination of trace CO in rotten blood, which provides an accurate and reliable method for the determination of $\mathrm{CO}$. While the methods mentioned above are mostly semi-quantitative, establishing a high sensitivity, good selectivity, simple operation and rapid detection method for $\mathrm{CO}$ is of great significance to environmental protection and human health. This paper studied the nano-catalytic reaction of $\mathrm{CO}-\mathrm{HAuCl}_{4}$-En, and established a new SERS/RRS coupled di-mode method for trace CO. Compared with the reported method of CO, this method has advantages of accuracy and high sensitivity.

\section{Materials and Methods}

\subsection{Apparatus}

A model of a DXR smart Raman spectrometer (Thermo Fisher Scientific, Waltham, MA, USA) with laser of $633 \mathrm{~nm}$, power of $2.5 \mathrm{~mW}$, collect time of $5 \mathrm{~s}$ and slit of $25 \mu \mathrm{m}$, a model of F-7000 Hitachi fluorescence spectrometer (Hitachi Company, Tokyo, Japan) with volt $=500 \mathrm{~V}$, excited slit $=$ emission slit $=5 \mathrm{~nm}$, emission filter $=1 \% \mathrm{~T}$ attenuator and $\lambda_{\mathrm{ex}}-\lambda_{\mathrm{em}}=\Delta \lambda=0$, and a model of TU-1901 double beam UV-Vis spectrophotometer (Beijing Purkinje General Instrument Co., Ltd., Beijing, China) were used. A model S-4800 scanning electron microscope (SEM, Hitachi High-Technologies Corporation, Tokyo, Japan) was used to record the SEM images. A model of JEM-800 H Field emission transmission electron microscope (Hitachi High-Technologies Corporation, Tokyo, Japan) was used to record the transmission electron microscope (TEM) and energy spectrum, with lattice resolution of $0.204 \mathrm{~nm}$, dot resolution of $0.45 \mathrm{~nm}$, acceleration voltage of $200 \mathrm{kV}$ and tilt angle of 25 degrees. A model of C-MAG HS7 Heating magnetic stirrer (IKA Company, Berlin, Germany), Constant temperature magnetic stirrer (Beijing Kewei Yongxing Instrument Company, Ltd., Beijing, China), and KC-6120 Atmospheric sampler (Laoshan Mountain Electronic Instrument Factory Company, Ltd., Laoshan, China) were used.

\subsection{Reagents}

A total of $20 \mathrm{~mL}$ water in a $25^{\circ} \mathrm{C}$ water bath in a $25 \mathrm{~mL}$ tube was used and filled carbon monoxide gas into the water for 10 min under the normal atmospheric pressure, in which the concentration of $\mathrm{CO}$ was $26.03 \mathrm{mg} / \mathrm{L}$ according to reference [39]. A $0.2 \mathrm{~mol} / \mathrm{L} \mathrm{HAc}-\mathrm{NaAc}$ (Shanghai Reagent Factory, Shanghai, China) buffer solution ( $\mathrm{pH}=5.2$ ) was made by mixing $79 \mathrm{~mL} 0.2 \mathrm{~mol} / \mathrm{L} \mathrm{NaAc} \mathrm{solution} \mathrm{with}$ $21 \mathrm{~mL} 0.3 \mathrm{~mol} / \mathrm{L}$ acetic solution then diluting to $100 \mathrm{~mL}$. A $1.0 \mathrm{mg} / \mathrm{mL} \mathrm{HAuCl}_{4}$ (Tianjin Guangfu Fine Chemical Research Institute, Tianjin, China) and $20 \mu \mathrm{mol} / \mathrm{L}$ Vitoria blue B (VBB, China Pharmaceutical Shanghai Chemical Reagent Station, Shanghai, China) solution was prepared. Ethanol, $\mathrm{PdCl}_{2}$, glucose and trisodium citrate were purchased from Shanghai Reagent Factory (Shanghai, China).

\subsection{Experiment Methods}

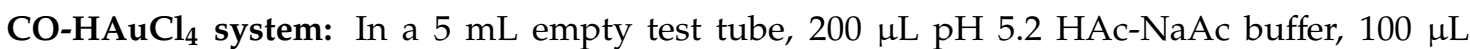
$0.2 \mathrm{mg} / \mathrm{mL} \mathrm{HAuCl}_{4}$ and $120 \mu \mathrm{L} 26.03 \mathrm{mg} / \mathrm{L} \mathrm{CO}$ were added and mixed well. After $5 \mathrm{~min}, 57 \mu \mathrm{L}$ $20 \mu \mathrm{mol} / \mathrm{L} \mathrm{VBB}$ and $30 \mu \mathrm{L} 1 \mathrm{~mol} / \mathrm{L} \mathrm{NaCl}$ solutions were added, shaken well, and then diluted to $1.5 \mathrm{~mL}$ with water. The SERS and RRS spectra were recorded through a Raman spectrometer and fluorescence spectrophotometer, respectively. The SERS at $1620 \mathrm{~cm}^{-1}$ (I) and RRS intensity at $290 \mathrm{~nm}\left(\mathrm{I}_{290 \mathrm{~nm}}\right)$, 
and the blank $\left[\mathrm{I}_{0},\left(\mathrm{I}_{290 \mathrm{~nm}}\right)_{0}\right]$ without of $\mathrm{CO}$ were recorded. The $\Delta \mathrm{I}=\mathrm{I}-\mathrm{I}_{0}$ and $\Delta \mathrm{I}_{290 \mathrm{~nm}}=\mathrm{I}_{290 \mathrm{~nm}}-$ $\left(\mathrm{I}_{290} \mathrm{~nm}\right)_{0}$ were calculated.

CO-HAuCl ${ }_{4}$-ethanol catalytic system: In a $5 \mathrm{~mL}$ empty test tube, $200 \mu \mathrm{L} \mathrm{pH} 5.2 \mathrm{HAc}-\mathrm{NaAc}$ buffer, $100 \mu \mathrm{L} 0.2 \mathrm{mg} / \mathrm{mL} \mathrm{HAuCl}_{4}$ and $120 \mu \mathrm{L} 26.03 \mathrm{mg} / \mathrm{L} \mathrm{CO}$ were added, diluted to $0.8 \mathrm{~mL}$ with water, and mixed well. After $5 \mathrm{~min}$, a $200 \mu \mathrm{L} 99.7 \%$ ethanol, $110 \mu \mathrm{L} 0.01 \mathrm{~mol} / \mathrm{L} \mathrm{HCl}$ and $80 \mu \mathrm{L} 1.0 \mathrm{mg} / \mathrm{mL}$ $\mathrm{HAuCl}_{4}$ were added. The tube was heated to $75{ }^{\circ} \mathrm{C}$ in a water bath for $20 \mathrm{~min}$, and cooled with ice-water. Then, $57 \mu \mathrm{L} 20 \mu \mathrm{mol} / \mathrm{L} \mathrm{VBB}$ and $30 \mu \mathrm{L} 1 \mathrm{~mol} / \mathrm{L} \mathrm{NaCl}$ solutions were added, and diluted to $1.5 \mathrm{~mL}$ with water. The SERS at $1620 \mathrm{~cm}^{-1}$ (I) and RRS intensity at $370 \mathrm{~nm}\left(\mathrm{I}_{370 \mathrm{~nm}}\right)$, and the blank $\left[\mathrm{I}_{0},\left(\mathrm{I}_{370} \mathrm{~nm}\right)_{0}\right]$ without of $\mathrm{CO}$ were recorded. The $\Delta \mathrm{I}=\mathrm{I}-\mathrm{I}_{0}, \Delta \mathrm{I}_{370 \mathrm{~nm}}=\mathrm{I}_{370 \mathrm{~nm}}-\left(\mathrm{I}_{370} \mathrm{~nm}\right)_{0}$ and $\Delta \mathrm{I}_{\text {Di-mode }}$ $=\Delta \mathrm{I}+\Delta \mathrm{I}_{370 \mathrm{~nm}}$ were calculated.

CO-PdCl ${ }_{2}$ system: In a $5 \mathrm{~mL}$ empty test tube, $200 \mu \mathrm{L} \mathrm{pH} 5.2 \mathrm{HAc}-\mathrm{NaAc}$ buffer, $150 \mu \mathrm{L} 0.1 \mathrm{mg} / \mathrm{mL}$ $\mathrm{PdCl}_{2}$ and $120 \mu \mathrm{L} 26.03 \mathrm{mg} / \mathrm{L} \mathrm{CO}$ were added, mixed well, and then diluted to $1.5 \mathrm{~mL}$ with water. After $5 \mathrm{~min}$, The RRS spectra were recorded through a fluorescence spectrophotometer. The RRS intensity at $370 \mathrm{~nm}(\mathrm{I})$, and the blank $\left(\mathrm{I}_{0}\right)$ without of $\mathrm{CO}$ were recorded. The $\Delta \mathrm{I}=\mathrm{I}-\mathrm{I}_{0}$ were calculated.

CO-HAuCl ${ }_{4}$-glucose catalytic system: In a $5 \mathrm{~mL}$ empty test tube, $200 \mu \mathrm{L} \mathrm{pH} 5.2 \mathrm{HAc}-\mathrm{NaAc}$ buffer, $100 \mu \mathrm{L} 0.2 \mathrm{mg} / \mathrm{mL} \mathrm{HAuCl}_{4}$ and $120 \mu \mathrm{L} 26.03 \mathrm{mg} / \mathrm{L} \mathrm{CO}$ were added, diluted to $0.8 \mathrm{~mL}$ with water, and mixed well. After $5 \mathrm{~min}, 100 \mu \mathrm{L} 0.1 \mathrm{~mol} / \mathrm{L}$ glucose, $100 \mu \mathrm{L} 0.01 \mathrm{~mol} / \mathrm{L} \mathrm{HCl}$ and $80 \mu \mathrm{L} 1.0 \mathrm{mg} / \mathrm{mL}$ $\mathrm{HAuCl}_{4}$ were added. The tube was heated in a $75^{\circ} \mathrm{C}$ water bath for $20 \mathrm{~min}$, and cooled with ice-water. Then, $57 \mu \mathrm{L} 20 \mu \mathrm{mol} / \mathrm{L} \mathrm{VBB}$ and $30 \mu \mathrm{L} 1 \mathrm{~mol} / \mathrm{L} \mathrm{NaCl}$ solutions were added, and diluted to $1.5 \mathrm{~mL}$ with water. The SERS at $1620 \mathrm{~cm}^{-1}(\mathrm{I})$, and the blank $\left(\mathrm{I}_{0}\right)$ without of $\mathrm{CO}$ were recorded. The $\Delta \mathrm{I}=\mathrm{I}-\mathrm{I}_{0}$ were calculated.

CO-HAuCl ${ }_{4}$-citrate catalytic system: In a 5 mL empty test tube, $200 \mu \mathrm{L} \mathrm{pH} 5.2$ HAc-NaAc buffer, $100 \mu \mathrm{L} 0.2 \mathrm{mg} / \mathrm{mL} \mathrm{HAuCl}_{4}$ and $120 \mu \mathrm{L} 26.03 \mathrm{mg} / \mathrm{L} \mathrm{CO}$ were added, diluted to $0.8 \mathrm{~mL}$ with water, and mixed well. After $5 \mathrm{~min}, 100 \mu \mathrm{L} 0.1 \mathrm{~mol} / \mathrm{L}$ trisodium citrate, $110 \mu \mathrm{L} 0.01 \mathrm{~mol} / \mathrm{L} \mathrm{HCl}$ and $80 \mu \mathrm{L}$ $1.0 \mathrm{mg} / \mathrm{mL} \mathrm{HAuCl}_{4}$ were added. The tube was heated in a $75^{\circ} \mathrm{C}$ water bath for $20 \mathrm{~min}$, and cooled with ice-water. Then, $57 \mu \mathrm{L} 20 \mu \mathrm{mol} / \mathrm{L} \mathrm{VBB}$ and $30 \mu \mathrm{L} 1 \mathrm{~mol} / \mathrm{L} \mathrm{NaCl}$ solutions were added, and diluted to $1.5 \mathrm{~mL}$ with water. The SERS at $1620 \mathrm{~cm}^{-1}(\mathrm{I})$, and the blank $\left(\mathrm{I}_{0}\right)$ without of $\mathrm{CO}$ were recorded. The $\Delta \mathrm{I}$ $=\mathrm{I}-\mathrm{I}_{0}$ were calculated.

The preparation of SEM samples: According to the experimental methods, $1.5 \mathrm{~mL}$ reaction solution was taken into a centrifuge tube for $20 \mathrm{~min}(150 \times 100 \mathrm{r} / \mathrm{min})$. Then, the supernatant was removed and diluted to $1.5 \mathrm{~mL}$, with $30 \mathrm{~min}$ ultrasonic oscillation. The latter was repeated twice and then $1.5 \mathrm{~mL}$ water was added; we then applied $2 \mu \mathrm{L}$ samples to the silicon wafers for natural drying. After all the steps mentioned above, SEM was performed.

The preparation of $\mathrm{CO}$ samples: A total of $10 \mathrm{~mL}$ absorb liquid ( $\mathrm{pH} 5.2$ buffer $+\mathrm{HAuCl}_{4}$ ) in $\mathrm{u}$-shaped tube, which connected to the atmospheric sampling instrument, sampling for $60 \mathrm{~min}$ with the flow velocity of $0.5 \mathrm{~L} / \mathrm{min}$, was used. Then, this was transferred into $5 \mathrm{~mL}$ colorimetric tubes. There were also some blank experiments being set for $\mathrm{CO}$ detection.

\section{Results and Discussion}

\subsection{Analytical Principle}

When a beam of light irradiates nanoparticles with molecules, it generates Rayleigh scattering and Raman scattering. Rayleigh scattering is an elastic scattering. Here, it was much greater than that of the Raman scattering intensity of inelastic scattering. That is to say, the inelastic scattering intensity can be ignored when compared with the Rayleigh scattering. When the molecules were adsorbed on the nanoparticle substrate that produced the SERS effect, the intensity was enhanced greatly. The total scattering intensity $\left(\mathrm{I}_{\mathrm{S}}\right)$ was the sum of RRS and SERS. That is, $\mathrm{I}_{\mathrm{S}}=\mathrm{I}_{\mathrm{RRS}}+\mathrm{I}_{\mathrm{SERS}}$. In order to achieve this goal, we explored the CO system with SERS and RRS effects.

$\mathrm{CO}$ has strong reducibility in a $\mathrm{pH} 5.2 \mathrm{HAc}-\mathrm{NaAc}$ buffer. Therefore, it can react with $\mathrm{HAuCl}_{4}$ to generate red gold nanoparticles, and with the increase of $\mathrm{CO}$ concentration, more gold nanoparticles 
are generated, and it has SERS activity and RRS effect. The RRS and SERS signals (in the presence of the SERS probe VBB) have a positive correlation with the concentration of $\mathrm{CO}$. According to this, two simple and rapid SERS and RRS methods can be established for the analysis of CO. Furthermore, the gold nanoparticles have rich free surface electrons that can enhanced the redox electron transfer and exhibit strong catalysis of the ethanol reduction of $\mathrm{HAuCl}_{4}$ to produce gold nanoparticles with SERS activity and RRS effects. It can be deduced from Equation 1 that under the catalysis of the gold nanoparticles $(\mathrm{Au})_{\mathrm{n}}$ generated in the first step, $\mathrm{HAuCl}_{4}$ is reduced to $\mathrm{Au}$ by ethanol, and finally autocatalytic growth occurs to AuNPs, and the corresponding ethanol is oxidized to acetic acid. Meanwhile, the formed small Au crystal nucleus also catalyzed the redox reaction of ethanol- $\mathrm{HAuCl}_{4}$, which is called autocatalysis. With the increase of CO concentration, the SERS, RRS and both sums increased linearly due to the gold nanoparticles increasing in the catalytic analytical system. Thus, a novel and highly sensitive SERS/RRS coupled di-mode method was established for the determination of trace $\mathrm{CO}$ (Figure 1).
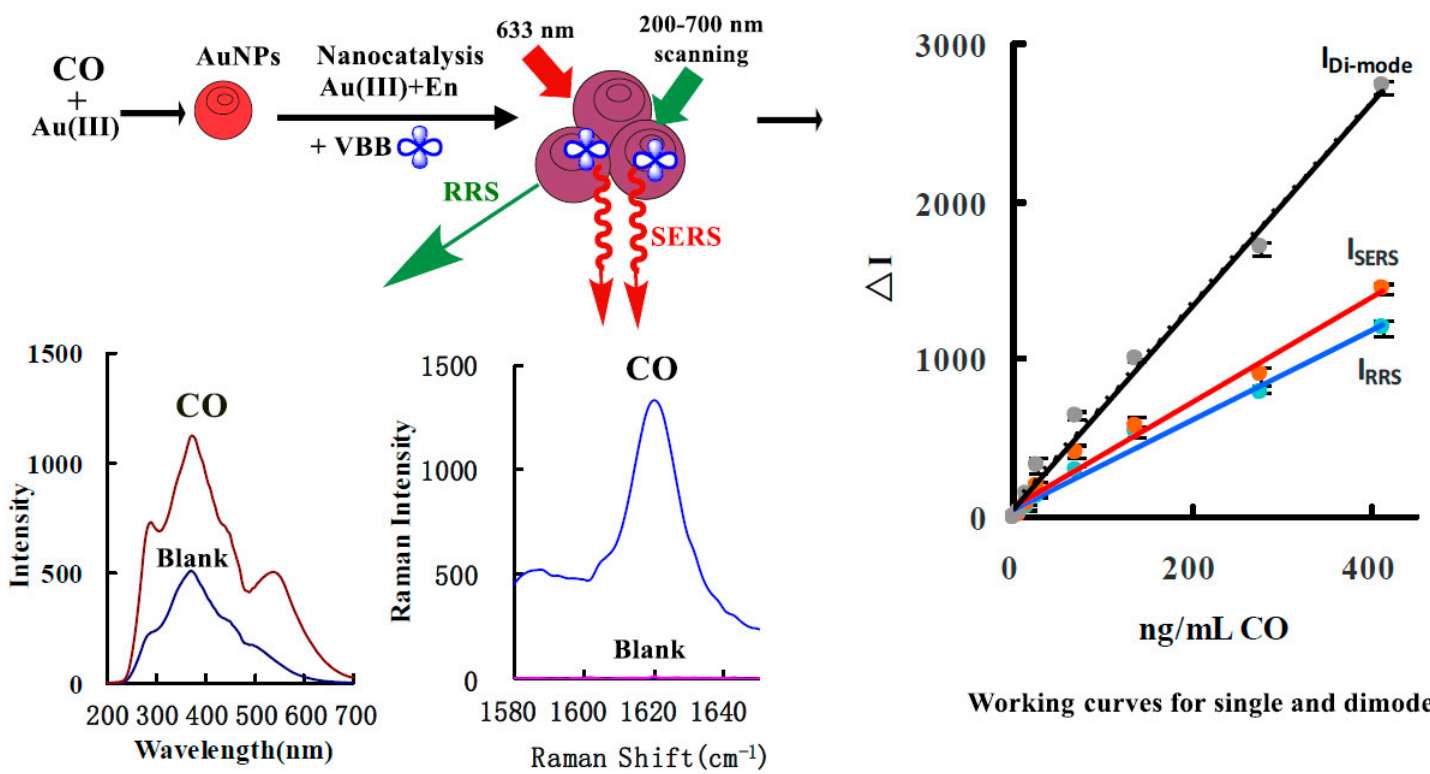

Working curves for single and dimode

Figure 1. Analytical principle of SERS/RRS coupled di-mode determination of CO by nanogold catalytic amplification.

Nanocatalytic reaction:

$$
\mathrm{HAuCl}_{4}+\text { ethanol }(\mathrm{En}) \underset{\text { catalysis }}{\stackrel{(\mathrm{Au}) \mathrm{n}}{\longrightarrow}} \mathrm{AuNPs}+\text { acetic acid }
$$

\subsection{SERS Spectra}

A normal Raman scattering signal is very weak, and SERS is very strong due to some organic molecules adsorbing on the surface of nanoparticles to produce the surface plasmon resonance scattering. In general, the SERS intensity responds to molecular probe concentrations. Recently, our group has found that the SERS intensity is also linear to the concentration of nanoparticles as a sole substrate when molecular probe concentrations are held constant. This has been used in SERS quantitative analysis. Using $\mathrm{VBB}$ as a molecular probe, the $\mathrm{CO}-\mathrm{HAuCl}_{4}$ system exhibited three weak SERS peaks at 1173, 1400 and $1620 \mathrm{~cm}^{-1}$ (Figure 2A). The peaks at 1173, 1400 and $1620 \mathrm{~cm}^{-1}$ are related to $-\mathrm{NH}_{2}$ and $\mathrm{C}-\mathrm{H}$ bending vibrations, and $\mathrm{C}=\mathrm{C}$ and $\mathrm{C}=\mathrm{N}$ stretching vibrations. The most sensitive peak at $1620 \mathrm{~cm}^{-1}$ was selected for use. In a $75{ }^{\circ} \mathrm{C}$ water bath, the reaction of $\mathrm{HAuCl}_{4}$-En is very slow. Using the AuNPs come from the CO-HAuCl 4 reaction as catalyst, the reaction of $\mathrm{HAuCl}_{4}-\mathrm{En}$ can quickly catalyze the production of gold nanoparticles. With the increase of CO concentration, 
the AuNPs produced by the first reaction of $\mathrm{CO}-\mathrm{HAuCl}{ }_{4}$ increase, and the reaction of $\mathrm{HAuCl}_{4}$-En was catalyzed by AuNPs to generate a large number of gold nanoparticles, and the SERS signal enhanced greatly (Figure $2 \mathrm{~B}$ ), and the peak is enhanced linearly with $\mathrm{CO}$ concentration increasing. In addition, both $\mathrm{HAuCl}_{4}$-gluose and $\mathrm{HAuCl}_{4}$-citrate systems also exhibit a strong SERS peak at $1620 \mathrm{~cm}^{-1}$, and its intensity also increased with CO concentration increasing (Figure S1).
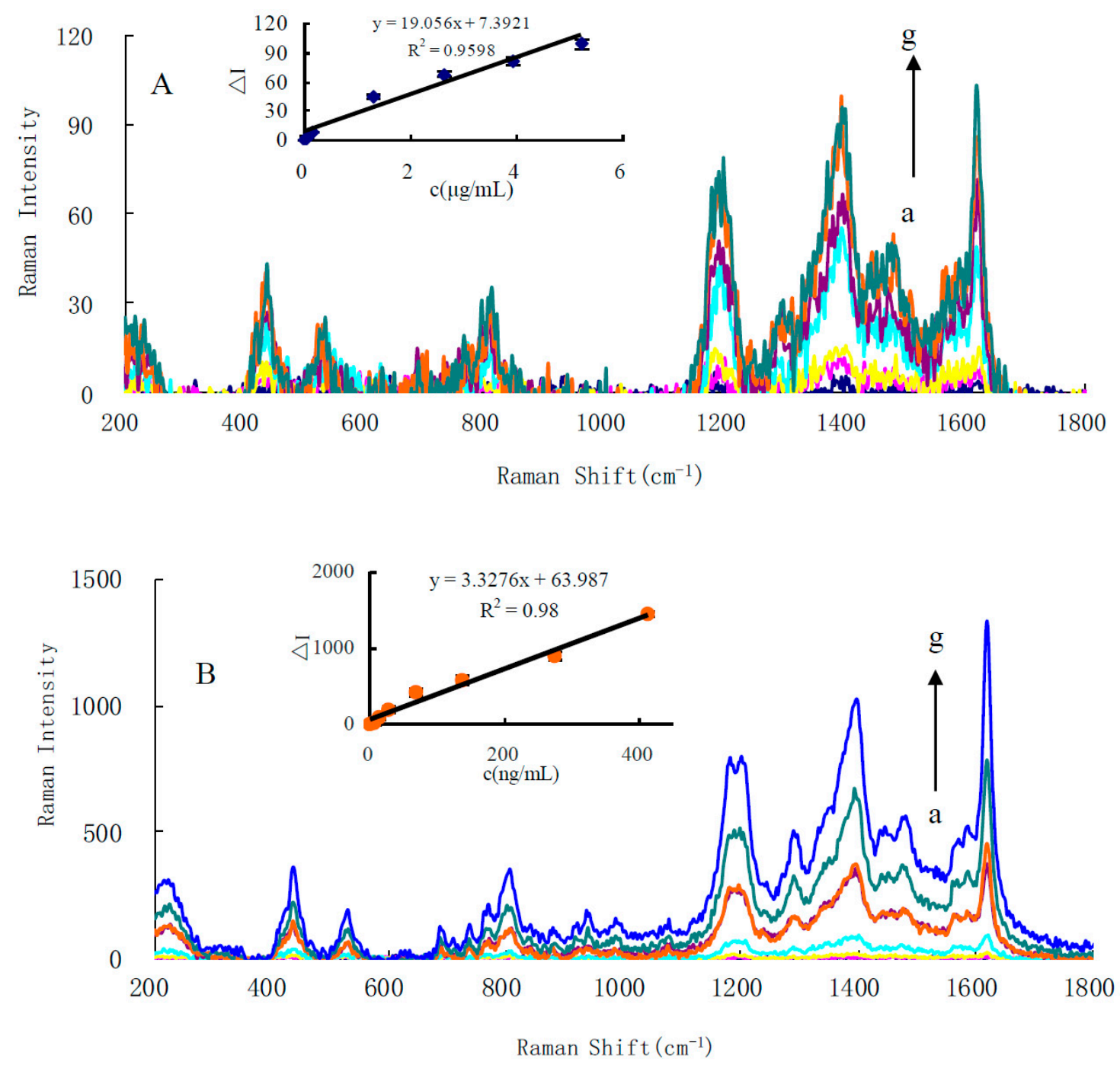

Figure 2. SERS spectra of (A) CO-HAuCl $\mathrm{H}_{4}-\mathrm{VBB}$ and (B) CO-HAuCl 4 -En-VBB systems. (A), a: $0.24 \mathrm{mmol} / \mathrm{L} \mathrm{pH} 5.2 \mathrm{HAc}-\mathrm{NaAc}+50.2 \mu \mathrm{g} / \mathrm{mL} \mathrm{HAuCl}_{4}+0.76 \mu \mathrm{mol} / \mathrm{L} \mathrm{VBB}+5.9 \mathrm{mmol} / \mathrm{L}$ $\mathrm{NaCl} ; \mathrm{b}: \mathrm{a}+0.03 \mu \mathrm{g} / \mathrm{mL} \mathrm{CO} ; \mathrm{c}: \mathrm{a}+0.13 \mu \mathrm{g} / \mathrm{mL} \mathrm{CO} ; \mathrm{d}: \mathrm{a}+0.31 \mu \mathrm{g} / \mathrm{mL}$ CO; e: a $+2.62 \mu \mathrm{g} / \mathrm{mL}$ CO; f: a + $3.92 \mu \mathrm{g} / \mathrm{mL} \mathrm{CO}$; g: a $+5.23 \mu \mathrm{g} / \mathrm{mL}$ CO. (B), a: $0.24 \mathrm{mmol} / \mathrm{L} \mathrm{pH} 5.2 \mathrm{HAc}-\mathrm{NaAc}+10.6 \%$ En + $0.58 \mathrm{mmol} / \mathrm{L} \mathrm{HCl}+52.9 \mu \mathrm{g} / \mathrm{mL} \mathrm{HAuCl}_{4}+0.76 \mu \mathrm{mol} / \mathrm{L} \mathrm{VBB}+5.9 \mathrm{mmol} / \mathrm{L} \mathrm{NaCl} ; \mathrm{b}: \mathrm{a}+13.8 \mathrm{ng} / \mathrm{mL}$ CO; c: a $+27.5 \mathrm{ng} / \mathrm{mL}$ CO; d: a $+68.9 \mathrm{ng} / \mathrm{mL} \mathrm{CO}$; : a $+137.7 \mathrm{ng} / \mathrm{mL}$ CO; f: a $+275.4 \mathrm{ng} / \mathrm{mL}$ CO; $\mathrm{g}: \mathrm{a}+413.2 \mathrm{ng} / \mathrm{mL} \mathrm{CO}$.

\subsection{RRS Spectra}

RRS is a kind of sensitive molecular spectral technology for the study of nanoparticles. For the $\mathrm{CO}-\mathrm{HAuCl}_{4}$ system, $\mathrm{CO}$ reacted with $\mathrm{HAuCl}_{4}$ to generate gold nanoparticles with an RRS peak at $290 \mathrm{~nm}$ (Figure 3A). In Figure 3A, no obvious RRS peak was observed around $530 \mathrm{~nm}$, mainly because the $\mathrm{CO}-\mathrm{HAuCl}_{4}$ system produced few gold nanoparticles and the Rayleigh scattering effect were not obvious, and the RRS intensity linearly enhanced with the increase of $\mathrm{CO}$ concentration in the range of $173.5-12,147.3 \mathrm{ng} / \mathrm{mL}$. For the CO-PdCl 2 system, there are two obvious RRS peaks at 270 and $360 \mathrm{~nm}$ 
(Figure S2). The RRS intensity at $360 \mathrm{~nm}$ is linear to $\mathrm{CO}$ concentration in the range of $0.1-2.0 \mu \mathrm{g} / \mathrm{mL} \mathrm{CO}$. Nano-catalysis is a new way to enhance analytical signals. Comparing the sensitivity of Pd (II)-CO and $\mathrm{Au}$ (III)-CO systems, it was found that the $\mathrm{Au}$ (III)-CO system was more sensitive. To increase the RRS sensitivity for detection of $\mathrm{CO}$, the $\mathrm{Au}$ (III)-CO system was coupled with nanocatalytic reaction. At $\mathrm{pH}$ 5.2, HAc-NaAc buffer, the CO-HAuCl 4 -En catalytic system exhibited three RRS peaks at 290, 370 and $535 \mathrm{~nm}$. The RRS peaks at 290 and $370 \mathrm{~nm}$ belong to the maximum emission peak of the light source, while the peak at $535 \mathrm{~nm}$ is the RRS peak of the spherical AuNPs. Because the intensity of the incident light is large, the RRS signal at $370 \mathrm{~nm}$ is stronger than the signal at $535 \mathrm{~nm}$ and the regularity is also very good. When $\mathrm{CO}$ concentration increases, the peak at $370 \mathrm{~nm}$ increases linearly, and this was selected for use (Figure 3B). In addition, the gold nanoparticles from the CO-HAuCl $\mathrm{H}_{4}$ reaction, also catalyzed the gold nano-reaction of $\mathrm{HAuCl}_{4}$-glucose. There were also three RRS peaks at 290, $370 \mathrm{~nm}$ and $535 \mathrm{~nm}$ (Figure S3). Similar to the reducer of En and glucose-containing alcohols, using glycerol as reducer, it also exhibited three RRS peaks at 290, 370 and $535 \mathrm{~nm}$ (Figure S4). As for the $\mathrm{CO}-\mathrm{HAuCl}_{4}$-citate catalytic system, it has two RRS peaks at 370 and $550 \mathrm{~nm}$ (Figure S5). Out of the four catalytic systems, the En system is most sensitive and was chosen for detection of CO.
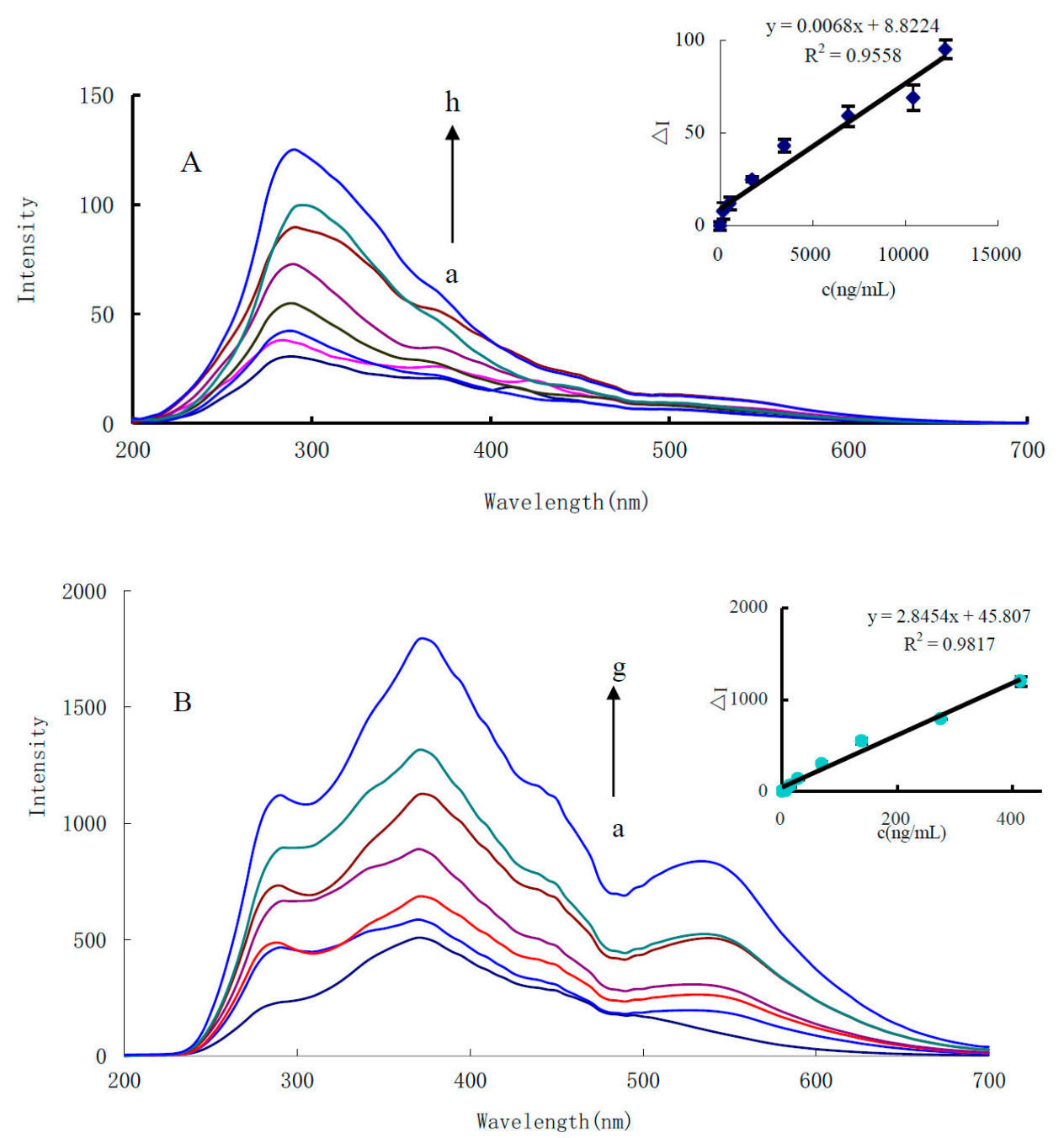

Figure 3. RRS spectra of (A) $\mathrm{CO}-\mathrm{HAuCl}_{4}$ system and (B) $\mathrm{CO}-\mathrm{HAuCl}_{4}$-En catalytic system. (A) a: pH $5.2 \mathrm{HAc}-\mathrm{NaAc}+13.3 \mu \mathrm{g} / \mathrm{mL} \mathrm{HAuCl}_{4}$; b: a $+173.5 \mathrm{ng} / \mathrm{mL} \mathrm{CO}$; : a $+520.6 \mathrm{ng} / \mathrm{mL} \mathrm{CO}$; d: a + $1735.3 \mathrm{ng} / \mathrm{mL} \mathrm{CO;} \mathrm{e:} \mathrm{a}+3470.7 \mathrm{ng} / \mathrm{mL} \mathrm{CO}$; : a $+6941.3 \mathrm{ng} / \mathrm{mL} \mathrm{CO;} \mathrm{g:} \mathrm{a} \mathrm{+} 10412.0 \mathrm{ng} / \mathrm{mL}$ CO; h: a + 12147.3 ng/mL CO. (B) a: pH 5.2 HAc-NaAc + 10.6\% En + 0.58 mmol/L HCl + 66.6 $\mu \mathrm{g} / \mathrm{mL}$ $\mathrm{HAuCl}_{4}$; b: a $+13.8 \mathrm{ng} / \mathrm{mL} \mathrm{CO}$; : a $+27.5 \mathrm{ng} / \mathrm{mL} \mathrm{CO}$; : a + $68.9 \mathrm{ng} / \mathrm{mL} \mathrm{CO}$; : a $+137.7 \mathrm{ng} / \mathrm{mL} \mathrm{CO}$; f: $\mathrm{a}+275.4 \mathrm{ng} / \mathrm{mL} \mathrm{CO} ; \mathrm{g}: \mathrm{a}+413.2 \mathrm{ng} / \mathrm{mL}$ CO. 


\subsection{UV Absorption Spectra}

$\mathrm{CO}$ could reduce $\mathrm{HAuCl}_{4}$ to generate AuNPs in the $\mathrm{pH} 5.2$ buffer solution, and the color of the system changed from colorless to pale blue. It had a weak surface plasma resonance (SPR) absorption peak at $548 \mathrm{~nm}$. Along with the increase of the $\mathrm{CO}$ concentration, the absorption peak at $548 \mathrm{~nm}$ intensity increased slowly (Figure 4A). The CO-HAuCl 4 -En catalytic system exhibited a strong absorption peak at $550 \mathrm{~nm}$, which was ascribed to the SPR absorption peak of AuNPs. With the increase of the $\mathrm{CO}$ concentration, the peaks increased (Figure 4B), but their sensitivity was lower than the RRS method.
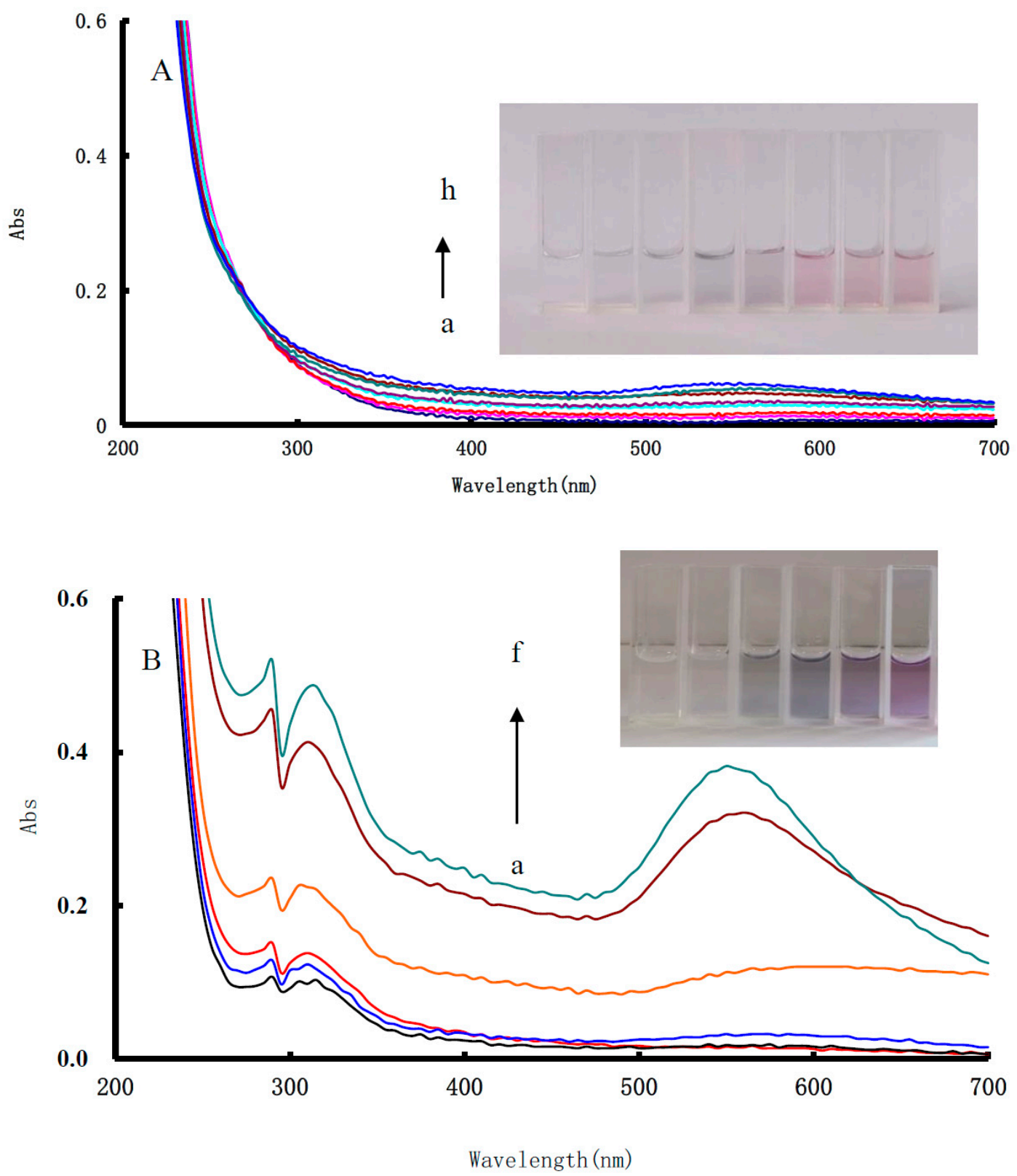

Figure 4. Absorption spectra of $\mathrm{CO}-\mathrm{HAuCl}_{4}$ system (A) and $\mathrm{CO}-\mathrm{HAuCl}_{4}$-En catalytic system (B). (A) a: pH $5.2 \mathrm{HAc}-\mathrm{NaAc}+13.3 \mu \mathrm{g} / \mathrm{mL} \mathrm{HAuCl}_{4} ; \mathrm{b}: \mathrm{a}+0.25 \mu \mathrm{g} / \mathrm{mL} \mathrm{CO} ; \mathrm{c}: \mathrm{a}+0.5 \mu \mathrm{g} / \mathrm{mL} \mathrm{CO}$; $\mathrm{d}: \mathrm{a}+1.0 \mu \mathrm{g} / \mathrm{mL}$ CO; e: a $+1.5 \mu \mathrm{g} / \mathrm{mL} \mathrm{CO}$; f: a $+2.0 \mu \mathrm{g} / \mathrm{mL} \mathrm{CO} ; \mathrm{g}: \mathrm{a}+2.5 \mu \mathrm{g} / \mathrm{mL} \mathrm{CO} ; \mathrm{h}: \mathrm{a}+3.125 \mu \mathrm{g} / \mathrm{mL}$ CO. (B) a: $0.24 \mathrm{mmol} / \mathrm{L} \mathrm{pH} 5.2 \mathrm{HAc}-\mathrm{NaAc}+10.6 \% \mathrm{En}+0.58 \mathrm{mmol} / \mathrm{L} \mathrm{HCl}+66.6 \mu \mathrm{g} / \mathrm{mL} \mathrm{HAuCl}_{4}$; b: a $+0.01 \mu \mathrm{g} / \mathrm{mL}$ CO; c: a $+0.03 \mu \mathrm{g} / \mathrm{mL} \mathrm{CO}$; : a $+0.07 \mu \mathrm{g} / \mathrm{mL}$ CO; e: a $+0.41 \mu \mathrm{g} / \mathrm{mL} \mathrm{CO}$; f: $\mathrm{a}+0.69 \mu \mathrm{g} / \mathrm{mL} \mathrm{CO}$. 


\subsection{Gold Nano-Enzyme Catalysis}

We known that $\mathrm{Au}^{3+}$ and En can adsorb on the surface of AuNPs from the CO-Au ${ }^{3+}$ reaction. The AuNPs have rich surface electrons that enhance the $\mathrm{Au}^{3+}$-En redox electron transfer to form more gold nanoparticles (Figure 5). The $\mathrm{Au}^{3+}$ was reduced step-by-step to $\mathrm{Au}^{+}$and $\mathrm{Au}$; meanwhile, the En was oxidized step-by-step to acetaldehyde (AD) and acetic acid (AA). We also need to pay attention to the catalytic effect of the Au nuclei formed by the redox reaction. That is to say, the autocatalytic reaction also exists in this system. At the same time, although $\mathrm{CO}$ reduces $\mathrm{Au}^{3+}$ at a high speed, the reduction ability is weak, so the SERS and RRS sensitivity of the first reaction is very weak. After the nanogold seed is generated through the first-step reaction, the nanogold seed can be used as a catalyst, which greatly improves the growth efficiency of gold nanoparticles. The specific reaction mechanism is shown in Figure 5.

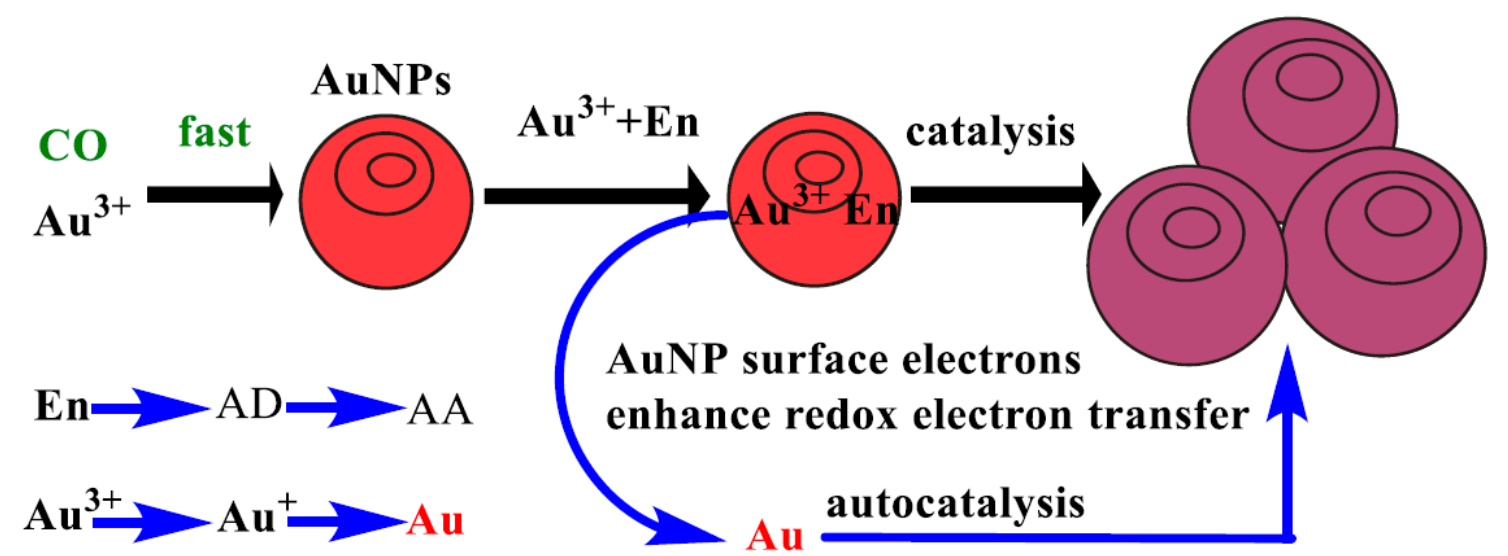

Figure 5. Mechanism of the AuNP catalysis of En reduction of $\mathrm{Au}^{3+}$.

\subsection{Scanning Electron Microscopy (SEM), Transmission Electron Microscope (TEM) and Energy Spectrum}

As the figure shows (Figure 6A), the gold nanoparticles of the $\mathrm{CO}-\mathrm{HAuCl}_{4}$ system have uniform particle sizes. In the TEM inset of Figure 6a, it can be seen that the average particle size of the gold nanoparticles is about $10 \mathrm{~nm}$. The energy spectrum diagram of the nanogold system was obtained by using a transmission electron microscope with $200 \mathrm{kV}$ voltage. The Au peaks appeared at 1.6, 2.1, 2.4 and $9.6 \mathrm{keV}$. The SEM diagram (TEM inset in Figure 6B) of $\mathrm{HAuCl}_{4}$-En was shown as in Figure 6b, with the progress of the catalytic reaction, $\mathrm{Au}$ (III)-En system produced more gold nanoparticles. They have four main spectral peaks at 1.6, 2.1, 2.4, and $9.6 \mathrm{keV}$, respectively, and the gold content is higher than that of the CO-Au (III) system. 


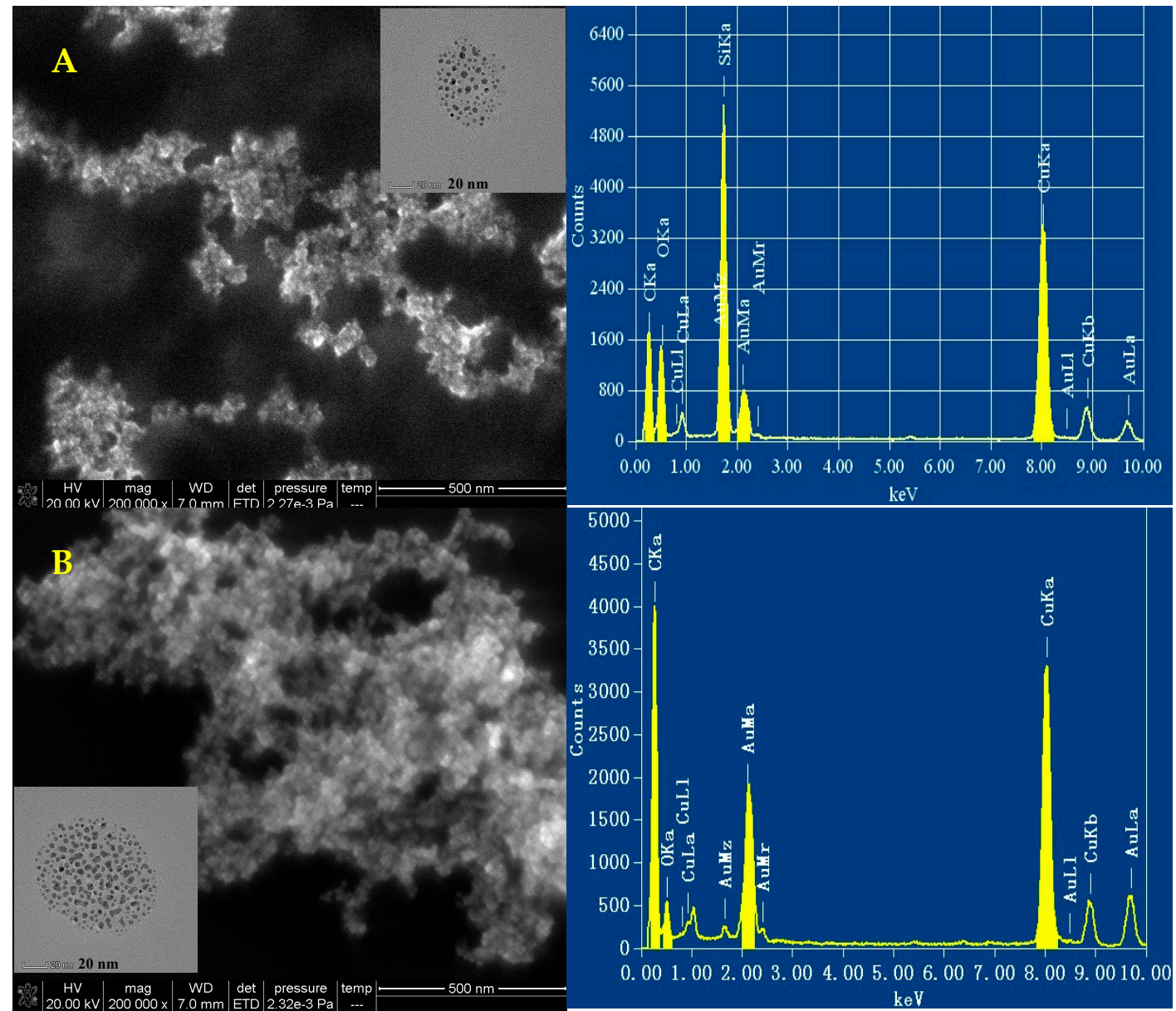

Figure 6. The SEM and energy spectral pictures. (A) $\mathrm{pH} 5.2$ buffer $+13.3 \mu \mathrm{g} / \mathrm{mL} \mathrm{HAuCl}_{4}+1.0 \mu \mathrm{g} / \mathrm{mL}$ $\mathrm{CO}$; (B) $\mathrm{pH} 5.2$ buffer $+66.6 \mu \mathrm{g} / \mathrm{mL} \mathrm{HAuCl}_{4}+1.0 \mu \mathrm{g} / \mathrm{mL} \mathrm{CO}+10.6 \%$ En.

\subsection{Conditions Optimization}

The two commonly used buffers including acetate and phosphate were considered, and the former was chosen in this study. As in Figure S6a, the $\mathrm{pH}$ of the acetate buffer solution was 5.2, which was achieved by a large $\Delta \mathrm{I}$ value, and was chosen for use. As shown in Figure S6b, when the buffer solution concentration reached $0.24 \mathrm{mmoL} / \mathrm{L}, \Delta \mathrm{I}$ was largest, which was why the buffer solution concentration was chosen as $0.24 \mathrm{mmol} / \mathrm{L}$ in this experiment. The effect of $\mathrm{HAuCl}_{4}$ concentration on the system $\Delta \mathrm{I}$ was also researched. When the concentration of $\mathrm{HAuCl}_{4}$ for the redox reaction was $13.3 \mu \mathrm{g} / \mathrm{mL}, \Delta \mathrm{I}$ was largest, so the concentration of $13.3 \mu \mathrm{g} / \mathrm{mL} \mathrm{HAuCl}_{4}$ was chosen (Figure S6c). The effect of $\mathrm{HAuCl}_{4}$ concentration of the nano-catalytic reaction on the $\Delta \mathrm{I}$ was also examined. Results (Figure S6d) show that when the concentration of $\mathrm{HAuCl}_{4}$ was $66.6 \mu \mathrm{g} / \mathrm{mL}$, the $\Delta \mathrm{I}$ was the largest, so the concentration of $66.6 \mu \mathrm{g} / \mathrm{mL} \mathrm{HAuCl}_{4}$ was chosen. When the En concentration was $10.6 \%(\mathrm{v} / \mathrm{v})$ in this experiment the $\Delta \mathrm{I}$ could achieve the largest in the condition (Figure S6e). The effect of reaction temperature and time on the $\Delta \mathrm{I}$ were examined. Results (Figure S6f,g) show that the tube was heated in a $75{ }^{\circ} \mathrm{C}$ water bath for $20 \mathrm{~min}$, giving the highest $\Delta \mathrm{I}$ value, and a reaction temperature of $75^{\circ} \mathrm{C}$ for heating for $20 \mathrm{~min}$ was selected for use. $\mathrm{NaCl}$ was a good sensitizer for improvement of SERS signals due to aggregation of the nanoparticles, the effect of its concentration shows that $20 \mathrm{mmol} / \mathrm{L}$ gives a high intensity and was chosen for use (Figure S6h). A $0.76 \mu \mathrm{mol} / \mathrm{L}$ VBB obtained the highest intensity and was selected for use (Figure S6i). 


\subsection{Calibration Curve}

The standard curves for SERS and RRS methods were obtained according to the experimental procedure. As for the system of $\mathrm{CO}-\mathrm{HAuCl}_{4}$, the $\mathrm{CO}$ concentration had a good linear relationship with $\Delta \mathrm{I}$ and $\Delta \mathrm{I}_{370 \mathrm{~nm}}$ when it was in the range of 30-5230 ng/mL and 100-1500 ng/mL, respectively. The SERS method is more sensitive than the RRS. To obtain high sensitivity and accuracy, the catalytic SERS, RRS and SERS/RRS working curves for the En system were examined as in Table 1 . It can be seen that the $\mathrm{HAuCl}_{4}$-En SERS/RRS di-mode method is the most sensitive and was chosen for use. The relative standard deviation of five determinations of $100 \mathrm{ng} / \mathrm{mL}$ CO by SERS, RRS and di-mode were $7.0 \%, 4.5 \%$, and 5.6\%, respectively. It was compared to the reported methods for CO [26-33,40-44] (Table S1), and the SERS/RRS coupled di-mode is one of the most sensitive methods.

Table 1. Analysis features of RRS and absorption methods for CO.

\begin{tabular}{cccccc}
\hline System & Methods & Regression Equation & LR (ng/mL) & Coefficient & DL (ng/mL) \\
\hline \multirow{2}{*}{$\mathrm{HAuCl}_{4}$} & SERS & $\Delta \mathrm{I}=0.019 \mathrm{C}+7.4$ & $30-5230$ & 0.9598 & $20 \pm 0.04$ \\
& RRS & $\Delta \mathrm{I}=0.0068 \mathrm{C}+8.8$ & $100-1500$ & 0.9558 & $80 \pm 0.13$ \\
$\mathrm{HAuCl}_{4}$-En & SERS & $\Delta \mathrm{I}=3.33 \mathrm{C}+63.9$ & $5.0-413$ & 0.9800 & $3 \pm 0.02$ \\
& RRS & $\Delta \mathrm{I}=2.84 \mathrm{C}+45.8$ & $10-413$ & 0.9817 & $6 \pm 0.05$ \\
& Di-mode & $\Delta \mathrm{I}=6.33 \mathrm{C}+62$ & $3.0-413$ & 0.9851 & $1 \pm 0.02$ \\
\hline
\end{tabular}

LR: linear range; DL: detection limit.

\subsection{The Influence of Coexisting Substance}

The interferences of common coexistence in the catalytic system were investigated according to the experimental procedure. The results (Table S2) show that the relative error was within $\pm 10 \%$. In the $\mathrm{CO}-\mathrm{HAuCl}_{4}$-En system, using acetate as the buffer solution, $10 \mu \mathrm{g} / \mathrm{mL} \mathrm{Ca}^{2+}, \mathrm{Zn}^{2+}, \mathrm{K}^{+}, \mathrm{BrO}_{3}{ }^{-}, \mathrm{Na}_{2} \mathrm{~S}$, $\mathrm{SeO}_{3}{ }^{2-}, \mathrm{Ni}^{2+}, \mathrm{Cr}^{3+}$, glucose, ethanol and methyl alcohol; $8 \mu \mathrm{g} / \mathrm{mL} \mathrm{Co}{ }^{2+}, \mathrm{Mg}^{2+}, \mathrm{Fe}^{3+}, \mathrm{Pb}^{2+}, \mathrm{Al}^{3+}, \mathrm{Mn}^{2+}$, $\mathrm{Na}_{2} \mathrm{~S}_{2} \mathrm{O}_{3}$ and formaldehyde has little effect on the determination of $0.1 \mu \mathrm{g} / \mathrm{mL} \mathrm{CO}$. The results show that this nano-catalytic SERS/RRS di-mode method had a good selectivity.

\subsection{Analysis of Samples}

When CO concentration was 667 ppm, about 50\% oxygen hemoglobin changed into carbonyl hemoglobin. As we know, CO is produced by burning cigarettes. Therefore, we measured six samples, like indoor air, burning gas and cigarette combustion gas, etc. According to the detection methods, there was no CO detected in Samples 1-3 (Table 2), which was due to no burning of carbon material. After burning paper and cigarettes, $\mathrm{CO}$ was found in the collected combustion gases. This is due to the incomplete burning of paper and cigarettes, which released the $\mathrm{CO}$ that can be detected by the di-mode method (Sample 4-6) with a relative standard deviation (RSD) of 1.8-4.2\%. The di-mode results were in agreement with that of CO-Pd(II) spectrophotometry which is a standard method. This indicates that this new method is accurate and reliable.

Table 2. Sample analysis results.

\begin{tabular}{cccccc}
\hline Samples & $\begin{array}{c}\text { Sampling } \\
\text { Temperature } \\
\left({ }^{\circ} \mathbf{C}\right)\end{array}$ & $\begin{array}{c}\text { Measured Value } \\
\left(\mathbf{m g} / \mathbf{m}^{\mathbf{3}}\right)\end{array}$ & $\begin{array}{c}\text { Average } \\
\left(\mathbf{m g} / \mathbf{m}^{\mathbf{3}}\right)\end{array}$ & $\begin{array}{c}\text { RSD } \\
\mathbf{( \% )}\end{array}$ & $\begin{array}{c}\text { Ref. Results } \\
\left(\mathbf{m g} / \mathbf{m}^{\mathbf{3}}\right)\end{array}$ \\
\hline 1 & 18 & Not detected & Not detected & - & Not detected \\
2 & 20 & Not detected & Not detected & - & Not detected \\
3 & 18 & Not detected & Not detected & - & Not detected \\
4 & 20 & 0.00760 .00740 .00730 .00750 .0073 & 0.00752 & 1.8 & 0.00810 \\
5 & 20 & 0.00390 .0040 .00380 .00390 .0041 & 0.00394 & 2.6 & 0.0035 \\
6 & 18 & 0.00110 .00120 .00120 .00110 .0012 & 0.00116 & 4.2 & 0.00120 \\
\hline
\end{tabular}




\section{Conclusions}

$\mathrm{CO}$ has strong reducibility in pH 5.2 HAc-NaAc buffer solution. So it can react with Au(III), generating Au nanoparticles, which exhibit SERS activity and RRS effects. With the increase of CO concentration, both scattering values also increased. Accordingly, two simple and rapid SERS and RRS methods for CO could be established, respectively. Based on the Au nanoparticle catalysis of $\mathrm{HAuCl}_{4}$-En to amplify the SERS and RRS signals, a new sensitive SERS/RRS coupled di-mode method was established for testing trace CO. This SERS/RRS coupled di-mode method was more sensitive than the two SERS and RRS single mode methods.

Supplementary Materials: The following are available online at http://www.mdpi.com/2079-4991/10/3/450/s1, Figure S1: SERS spectra; Figure S2: The RRS spectra of $\mathrm{CO}-\mathrm{PdCl}_{2}$ system; Figure S3: RRS spectra of CO-HAuCl${ }_{4}$-glucose nanocatalytic system; Figure S4: RRS spectra of CO-HAuCl 4 -glycerol system; Figure S5: RRS spectra of CO-HAuCl${ }_{4}$-citrate system; Figure S6: Effect of reaction conditions including reagent concentration, reaction temperature and time on the $\Delta \mathrm{I}$ value. Table S1: Comparison of some reported methods for CO; Table S2: The effect of coexistence on the determination of CO.

Author Contributions: G.W., and A.L. supervision; Z.J. proposed the concept and designed the experiment; D.Y., and L.G. contributed to the measurement results; C.L., and D.Y. wrote the original draft. G.W. and D.Y. were equality to the work. All authors have read and agreed to the published version of the manuscript.

Funding: This work was supported by the National Natural Science Foundation of China (No. 21667006, 21767004) and the Natural Science Foundation of Guangxi Province (No. 2018GXNSFAA138019).

Conflicts of Interest: The authors declare no conflict of interest.

\section{References}

1. Shi, W.; Zhang, X.; He, S.; Li, J.; Huang, Y. Fast screening of the nanoparticles-based enzyme mimetics by a chemiluminescence method. Sci. Sin. Chim. 2013, 43, 1591-1598. [CrossRef]

2. Chang, C.C.; Chen, C.P.; Wu, T.H.; Yang, C.H.; Lin, C.W.; Chen, C.Y. Gold nanoparticle-based Colorimetric Strategies for chemical and biological sensing applications. Nanomaterials 2019, 9, 861. [CrossRef] [PubMed]

3. Mandal, T.K.; Hou, Y.; Gao, Z.; Ning, H.; Yang, W.; Gao, M. Graphene oxide-based Sensor for ultrasensitive visual detection of fluoride. Adv. Sci. 2016, 3, 1600217-1600222. [CrossRef] [PubMed]

4. Chen, H.Y.; Qiu, Q.M.; Sharif, S.; Ying, S.N.; Wang, Y.X.; Ying, Y.B. Solution-phase synthesis of platinum nanoparticle-decorated metal-organic framework hybrid nanomaterials as biomimetic nano-enzymes for biosensing applications. ACS Appl. Mater. Interfaces 2018, 10, 24108-24115. [CrossRef]

5. Gao, L.Z.; Zhuang, J.; Nie, L. Intrinsic peroxidase-like activity of ferromagnetic nanoparticles. Nat. Nanotechnol. 2007, 2, 577-583. [CrossRef]

6. Wu, T.T.; Ma, Z.Y.; Li, P.P.; Lu, Q.J.; Liu, M.L.; Li, H.T.; Zhang, Y.Y.; Yao, S.Z. Bifunctional colorimetric biosensors via regulation of the dual nano-enzyme activity of carbonized FeCo-ZIF. Sens. Actuators B 2019, 290, 357-363. [CrossRef]

7. Li, Y.; Ma, Q.; Liu, Z.P.; Wang, X.Y.; Su, X.G. A novel enzyme-mimic nanosensor based on quantum dot-Au nanoparticle@silica mesoporous microsphere for the detection of glucose. Anal. Chim. Acta 2014, 840, 68-74. [CrossRef]

8. Zeng, H.H.; Qiu, W.B.; Zhang, L.; Liang, R.P.; Qiu, J.D. Lanthanide coordination polymer nanoparticles as an excellent artificial peroxidase for hydrogen peroxide detection. Anal. Chem. 2016, 88, 6342-6348. [CrossRef]

9. Jiang, X.; Sun, C.J.; Guo, Y. Peroxidase-like activity of apoferritin paired gold clusters for glucose detection. Biosens. Bioelectron. 2015, 64, 165-170. [CrossRef]

10. Liu, J.B.; Hu, X.N.; Hou, S. Au@Pt core/shell nanorods with peroxidase- and ascorbate oxidase-like activities for improved detection of glucose. Sens. Actuators B 2012, 166-167, 708-714. [CrossRef]

11. Liang, A.H.; Li, C.N.; Li, D.; Luo, Y.H.; Wen, G.Q.; Jiang, Z.L. A facile and sensitive peptide-modulating graphene oxide nanoribbon catalytic nanoplasmon analytical platform for human chorionic gonadotropin. Inter. J. Nanomed. 2017, 12, 8725-8734. [CrossRef] [PubMed]

12. Li, C.N.; Peng, Y.T.; Wang, H.D.; Liang, A.H.; Jiang, Z.L. A nanosol SERS method for quantitative analysis of trace potassium based on aptamer recognition and silver nanorod catalysis of $\mathrm{Ag}(\mathrm{I})$-glucose reaction. Sens. Actuators B 2019, 281, 53-59. [CrossRef] 
13. Xu, M.; Tu, G.; Ji, M.; Wan, X.; Liu, J.; Liu, J.; Rong, H.; Yang, Y.; Wang, C.; Zhang, J. Vacuum-tuned-atmosphere induced assembly of Au@Ag core/shell nanocubes into multi-dimensional superstructures and the ultrasensitive IAPP proteins SERS detection. Nano Res. 2019, 12, 1375-1379. [CrossRef]

14. Li, D.; Li, C.N.; Liang, A.H.; Jiang, Z.L. SERS and fluorescence dual-mode sensing trace hemin and K+ based on Gquarplex/hemin DNAzyme catalytic amplification. Sens. Actuators B 2019, 297, 126799. [CrossRef]

15. Ji, W.; Li, L.; Song, W.; Wang, X.; Zhao, B.; Ozaki, Y. Enhanced Raman scattering by ZnO superstructures: Synergistic effect of charge transfer and mie resonances. Angew. Chem. Int. Ed. 2019, 58, 14773. [CrossRef]

16. Zhou, X.; Liu, G.Q.; Zhang, H.W.; Li, Y.; Cai, W.P. Porous zeolite imidazole framework-wrapped urchin-like $\mathrm{Au}-\mathrm{Ag}$ nanocrystals for SERS detection of trace hexachlorocyclohexane pesticides via efficient enrichment. J. Hazard. Mater. 2019, 368, 429-435. [CrossRef] [PubMed]

17. Pandeeswar, M.; Rohilla, S.; Ahmad, E.K.; Selvakannan, R.P.; Ylias, M.S.; Chilakapati, M.; Suresh, K.B.; Thimmaiah, G. SERS and fluorescence-based ultrasensitive detection of mercury in water. Biosens. Bioelectron. 2018, 100, 556-564.

18. Ren, W.; Zhang, Y.; Fan, Y.Z.; Dong, J.X.; Li, N.B.; Luo, H.Q. A resonance Rayleigh scattering sensor for detection of $\mathrm{Pb} 2+$ ions via cleavage-induced G-wire formation. J. Hazard. Mater. 2017, 336, 195-201. [CrossRef]

19. Wang, H.; Huang, X.; Wen, G.; Jiang, Z.L. A dual-model SERS and RRS analytical platform for Pb(II) based on Ag-doped carbon dot catalytic amplification and aptamer regulation. Sci. Rep. 2019, 9, 9991. [CrossRef]

20. Jiang, Z.L.; Liao, X.J.; Deng, A.P.; Liang, A.H.; Li, J.S.; Pan, H.C.; Li, J.F.; Wang, S.M.; Huang, Y.J. Catalytic effect of nanogold on $\mathrm{Cu}(\mathrm{II})-\mathrm{N}_{2} \mathrm{H}_{4}$ reaction and its application to resonance scattering immunoassay. Anal. Chem. 2008, 80, 8681-8687. [CrossRef]

21. Liang, A.H.; Zhang, Y.; Fan, Y.Y.; Chen, Q.; Wen, G.Q.; Liu, Q.Y.; Kang, C.Y.; Jiang, Z.L. Catalysis of aptarmer-modified AuPdNPs nanoalloy probe and its application to resonance scattering detection of trace $\mathrm{UO}_{2}{ }^{2+}$. Nanoscale 2011, 3, 3178-3184. [CrossRef] [PubMed]

22. Ren, W.; Zhang, Y.; Chen, H.G.; Gao, Z.F.; Li, N.B.; Luo, H.Q. Ultrasensitive label-free resonance Rayleigh scattering aptasensor for $\mathrm{Hg}^{2+}$ using $\mathrm{Hg}^{2+}$-triggered exonuclease III-assisted target recycling and growth of G-wires for signal amplification. Anal. Chem. 2016, 88, 1385-1390. [CrossRef] [PubMed]

23. Zhou, J.; Ling, Y.; Li, N.B.; Luo, H.Q. Fluorometric and resonance Rayleigh scattering dual-mode bioprobe for determination of the activity of alkaline phosphatase based on the use of $\mathrm{COOH}$ nanoflakes and cobalt(II)-dependent DNAzyme-assisted amplification. Microchim. Acta 2019, 186, 437. [CrossRef] [PubMed]

24. Wang, X.Y.; Jiang, X.; Zhang, Z.H.; Li, J.; Liang, A.H.; Jiang, Z.L. A fluorescence and resonance Rayleigh scattering di-model probe was developed for trace $\mathrm{K}^{+}$coupled $\mathrm{N}$-doped carbon dot and aptamer. J. Lumin. 2019, 214, 116559. [CrossRef]

25. Wen, G.Q.; Yang, D.; Jiang, Z.L. A new resonance Rayleigh scattering spectral method for determination of $\mathrm{O}_{3}$ with victoria blue B. Spectrochim. Acta Part A 2014, 117, 170-174. [CrossRef]

26. Guo, Z.P. The pollution and detection of carbon monoxide. Environ. Sci. Techn. 2000, 13, 44.

27. Phawachalotorn, C.; Sanguanruang, O.; Ishihara, T. Highly selective amperometric sensors for carbon monoxide detection in exhaust gas. Sens. Actuators B 2012, 161, 635-640. [CrossRef]

28. Blondeau-Patissier, V.; Vanotti, M.; Pretre, T.; Rabus, D.; Tortora, L.; Barbe, J.M.; Ballandras, S. Detection and monitoring of carbon monoxide using cobalt corroles film on love wave devices with delay line configuration. Procedia Eng. 2011, 25, 1085-1088. [CrossRef]

29. Kim, B.; Lu, Y.J.; Hannon, A.; Meyyappan, M.; Li, J. Low temperature $\mathrm{Pd} / \mathrm{SnO}_{2}$ sensor for carbon monoxide detection. Sens. Actuators B 2013, 177, 770-775. [CrossRef]

30. Boehm, G.; Bachmann, A.; Rosskopf, J.; Ortsiefer, M.; Chen, J.; Hangauer, A.; Meyer, R.; Strzoda, R.; Amann, M.C. Comparison of InP- and GaSb-based VCSELs emitting at $2.3 \mu \mathrm{m}$ suitable for carbon monoxide detection. J. Crystal Growth 2011, 323, 442-445. [CrossRef]

31. Wang, R.X.; Zhang, D.J.; Liu, C.B. The germanium-doped boron nitride nanotube serving as a potential resource for the detection of carbon monoxide and nitric oxide. Comput. Mater. Sci. 2014, 82, 361-366. [CrossRef]

32. Ghosh, S.; Narjinary, M.; Sen, A.; Bandyopadhyay, R.; Roy, S. Fast detection of low concentration carbon monoxide using calcium-loaded tin oxide sensors. Sens. Actuators B 2014, 203, 490-496. [CrossRef]

33. Chen, D.; Sun, Y.; Li, J.; Ren, J. Determination of carbon monoxide content in water during euthanasia of tilapia by dual-wavelength spectrophotometry method. Food Sci. Technol. 2011, 36, 283-286. 
34. Chen, C.; Ren, Q.; Piao, H.; Wang, P.; Wang, Y. A trace carbon monoxide sensor based on differential absorption spectroscopy using mid-infrared quantum cascade laser. Micromachines 2018, 9, 670. [CrossRef] [PubMed]

35. Zoltan, B.; Andras, G.; Krisztian, H.; Janos, M. Determination of carbon monoxide concentration and total pressure in gas cavities in the silica glass body of light bulbs by FT-IR spectrometry. Anal. Chem. 2006, 78, 2382-2387.

36. Wang, P.; Huang, L.; Zhou, Y.; Zhao, H.; Fang, Y.; Xue, C. Determination of carbon monoxide in aquatic products by headspace gas chromatography. J. Zhejiang Ocean Univ. 2012, 31, 518-520.

37. Wang, Z.; Liu, C.; Wang, X.; Duan, Q.; Jia, P.; Zhu, H.; Li, Z.; Zhang, X.; Ren, X.; Zhu, B.; et al. A metal-free near-infrared fluorescent probe for tracking the glucose induced fluctuations of carbon monoxide in living cells and zebrafish. Sens. Actuators B 2019, 291, 329-336. [CrossRef]

38. Hao, H.X.; Zhou, H.; Liu, X.P.; Zhang, Z.; Yu, Z.S. An accurate method for microanalysis of carbon monoxide in putrid postmortem blood by head-space gas chromatography-mass spectrometry (HS/GC/MS). Forensic Sci. Int. 2013, 229, 116-121. [CrossRef]

39. Dean, J.A. Lange's Handbook of Chemistry, 15th ed.; MeGraw-Hill: New York, NY, USA, 1999.

40. Dong, L.; Lewicki, R.; Liu, K.; Buerki, P.R.; Weida, M.J.; Tittel, F.K. Ultra-sensitive carbon monoxide detection by using EC-QCL based quartz-enhanced photoacoustic spectroscopy. Appl. Phys. B 2012, 107, 275-283. [CrossRef]

41. Zhang, Y.; Cui, S.M.; Chang, J.B.; Leonidas, E.O.; Chen, J.H. Highly sensitive room temperature carbon monoxide detection using $\mathrm{SnO}_{2}$ nanoparticle-decorated semiconducting single-walled carbon nanotubes. Nanotechnology 2013, 24, 477-487.

42. Khalil, A.I.; Gondal, A.M.; Al-Suliman, N. Resonant photo-acoustic detection of carbon monoxide with UV Laser at 213 nm. Appl. Phys. B 2011, 103, 441-450. [CrossRef]

43. Antonaroli, S.; Crociani, B.; Natale, C.D.; Nardis, S.; Stefanelli, M.; Paolesse, R. Palladium complexes based nano gravimetric sensors for carbon monoxide detection. Sens. Actuators B 2015, 208, 334-338. [CrossRef]

44. Selvapathy, P. Rapid spectrophotometric determination of carbon monoxide in ambient air. Environ. Protection Xinjiang 1992, 14, 44-48. [CrossRef] 